\title{
Chile along the road. Changes and continuities of the Chilean development model in the context of the Belt and Road Initiative
}

\author{
Chile a lo largo de la ruta. Cambios y continuidades del modelo \\ de desarrollo chileno en el contexto de la Iniciativa de la Franja y la Ruta \\ Javiera Flores \\ (School of Marxism, Yangtze University, Jingzhou and Wuhan, People's Republic of China)
}

Cita bibliogràfica: Flores, J. (2021). Chile along the road. Changes and continuities of the Chilean development model in the context of the Belt and Road Initiative. Disjuntiva, 2(2), 23-33. https://doi.org/10.14198/DISJUNTIVA2021.2.2.2

\begin{abstract}
Resumen
En 2013, el presidente chino, Xi Jinping, anunció el desarrollo de un proyecto de infraestructura y conectividad global, conocido hoy en día como la Iniciativa de la Franja y la Ruta (一带 一路). Aunque originalmente se presentó como un proyecto comercial centrado en Europa y Asia, a lo largo de los años, la Iniciativa de la Franja y la Ruta se ha convertido en un proyecto mucho más complejo. Recientemente, se ha extendido a más territorios, uno de ellos la región de América Latina y el Caribe. Chile, por su parte, ya firmó acuerdos de cooperación en torno a la Iniciativa, y ya se están desarrollando proyectos de cooperación entre ambos países en dimensiones comerciales y de telecomunicaciones. El presente artículo pretende discutir los cambios y continuidades que la cooperación entre Chile y China, en el ámbito de la Iniciativa, prevé para los desafíos de desarrollo sostenible que enfrenta Chile. El artículo sostiene que las dimensiones de cooperación entre ambos países representan elementos tanto de cambios como de continuidades para el modelo de desarrollo de Chile.
\end{abstract}

\section{Palabras claves}

La Franja y la Ruta; cooperación comercial; infraestructura digital; desarrollo sostenible.

\begin{abstract}
In 2013, Chinese President Xi Jinping announced the development of a massive project of global connectivity infrastructure, known nowadays as the Belt and Road Initiative (一带一路). Although it was originally presented as a trade project focused on Europe and Asia, through the years the Belt and Road Initiative has been unravelled as a much more complex project. Lately, it has been extended to more territories, one of them being Latin America and the Caribbean region. Chile has already signed cooperation agreements regarding the Initiative, and cooperation in trade and connectivity between Chile and China is already taking place. This article will discuss the changes and continuities that the cooperation between Chile and China, under the scope of the Initiative, provides for the sustainable development challenges Chile faces. The article concludes that the cooperation dimensions between both countries represent elements of both changes and continuities for the model of development of Chile.
\end{abstract}

\section{Key words}

Belt and Road Initiative; trade; digital infrastructure; sustainable development.

e-mail of the corresponding author: javiera.flores.u@gmail.com 


\section{Introduction}

The United Nations (UN) defines sustainable development as the "development that meets the needs of the present without compromising the ability of future generations to meet their own needs" (1987, 3.- Sustainable Development). The concept was introduced since the world had experienced unparalleled progress since the Industrial Revolution, but this progress came along with severe levels of poverty and environmental depletion, leading to non-promising conditions for future generations (1987). Therefore, in order to achieve sustainable development, it is required to harmonise three interconnected dimensions: environmental protection, social inclusion, and economic growth (UN, n.d.). All in all, sustainable development requires a process of change in the type of economic growth experienced by both wealthy and poor countries, whilst poverty is considered no longer inevitable and these socio-economic features are correlated to environmental catastrophes (UN, 1987).

Although Chile has achieved economic success, the issues caused by a non-sustainable pattern of development have become more visible in recent years. Since the restoration of democracy in 1990, Chile has accomplished high and steady economic growth and the building of stable political institutions. However, Chilean society has developed a tendency of social mobilisation, in many cases reaching a nationwide magnitude and becoming a destabilising factor on the political and economic system. Social mobilisation has frequently portrayed the socio-economic and socio-environmental issues associated with the economic growth of Chile. Furthermore, experts have shown concern about the problems that the Chilean economy faces in order to sustain its productivity, mainly because of the lack of sustainable management of natural resources.

Despite the aforementioned problems, Chile has not shown any attempt to change from a fundamental point of view the development model of the country. Currently, Chile is a strong supporter of the Belt and Road Initiative (from now on "BRI"), a Chinese megaproject of development focused on trade and infrastructure funding.

The cooperation between China and Chile, in the context of the BRI, can be addressed through two dimensions of cooperation: the deepening of trade between both countries and the participation of Chinese companies in the execution of a Chilean telecommunication network agenda. In this context, it is interesting to examine which changes and which continuities the current China-Chile cooperation represents to the development model of Chile. The continuities or changes will be addressed through the key dimensions of sustainable development: social, environmental, and economic.

The article will argue that the cooperation between both countries will maintain the focus of the Chilean economy on economic openness, especially through agriculture and natural resources exports. On the other hand, it will also discuss how the digital infrastructure projects represent an innovation in social, economic, and environmental dimensions, and has the potential to positively impact Chile's path to sustainable development.

The article is divided into five sections. The first section serves as a brief background description of the Chilean case, especially of the features and challenges that its model of development has presented. The second section introduces the Belt and Road Initiative and the cooperation dimensions of China and Chile within this Initiative. The third section gives a discussion of the elements of continuity presented by the dimension of commercial cooperation between both countries. The fourth section introduces the elements of change offered by the technological agenda of Chile. Finally, the fifth section serves as a conclusion.

\section{Background of the Chilean Case}

During the past thirty years of democracy, Chile has adopted a development model centred on economic openness, a free-market economy, and the encouragement of extensive international investment. In addition, Chile has often been recognised as an example of the consolidation of democratic institutions, which has situated this country as a political example in the Latin America and the Caribbean (LAC) region. The good economic and political position of Chile, and the provision of a friendly environment for foreign investment, have improved the chances of Chile to be a commercial partner and funding recipient of numerous countries (Ominami, 2010). Nevertheless, during recent years, the development model followed by Chile has shown several sustainability shortcomings.

Chile is rich in natural resources and fertile land and has developed an economy strongly dependent on raw material exports. Moreover, the economic integration approach of Chile has allowed the country to enjoy the largest trade agreements 
network in the world, being able to access the $60 \%$ of the wealth of the world (Organisation of Economic Cooperation and Development [OECD], 2018 quoted in Undersecretariat of Foreign Economic Affairs, 2019), whilst becoming the most competitive economy of the LAC region (Klaus \& World Economic Forum, 2019). But, regardless of the economic growth achieved by Chile, the attention has gradually shifted towards the productivity challenges that the model currently endures.

The Chilean economy faces important obstacles to sustain its further productivity. Both the depletion of the environment produced by the extraction processes and the lack of sophistication of the Chilean industry are associated with the stagnation of the productive sector, which leads to a non-promising economic future (French-Davis \& Díaz, 2019). The stagnation is particularly concerning as Chile has carried out a non-diversification pattern of commodities production during, at least, the last fifty years. These circumstances require the active action of the state on investment in innovation and diversification plans of the productive sectors (Martner, 2017).

Chile has achieved political consolidation as well, yet the persistent mobilisation within Chilean society has exhibited some of the limits of Chilean democracy. Although the Chilean model was able to reduce poverty and destitution and improved the quality of life of Chileans (Ominami, 2010), the country still shows high levels of concentration of wealth (United Nations Economic Commission for Latin America and the Caribbean [ECLAC], 2019), whilst the private sector is appointed as the main provider of social services (Vergara, 2005). The lack of distribution of wealth has produced, amongst other things, large disconformity by the citizenry towards both political and economic systems (Huneeus, 2018).

Inequality issues have been frequently portrayed in social mobilisation for the past two decades, but a critical stage took place in the 2019 Social Outbreak, arguably the most important social movement Chile has experienced since the restoration of democracy. According to Castiglioni (2019), the low middle class contains great amounts of frustration as a consequence of the disparity of access, quality, and sufficiency regarding social services and employment. Indeed, the massive social mobilisations of 2019 are, amongst other things, a consequence of this irritation, as well as the people's clash with the Chilean economic model.

Environmentally, Chile has also shown a twofold performance, on the one hand, making several environmental welfare accomplishments, yet, on the other hand, showing dissatisfactory practices according to some environmental standards.

Chile has been given an eco-friendly image by the international community, mainly because of certain environmental protection initiatives such as the pioneer governance over Marine Protected Areas (World Ocean Initiative, 2020), the full prohibition of plastic bags in commercial stores (Norman, 2020), the massive expansion of the renewable energy market (Londoño, 2017), as well as a good performance in environmental health, which encompasses the ability to manage solid waste and to prevent heavy metal exposure (Wendling et al., 2020), amongst others.

Regardless of the satisfactory performance in some aspects, the weak environmental framework often allows projects after taking into consideration economic interest over social and environmental safety (Madariaga, 2018 quoted in Carrasco \& Maillet, 2019). Subsequently, the performance of Chile regarding ecosystem vitality is more than deficient, showing negative results on preventing pollution and climate change, as well as presenting large losses in agricultural land, environmental services, and fisheries (Wendling, Emerson, de Sherbinin \& Esty, 2020), which might be explained by the lack of sustainability in Chile's processes of production and the intensive environmental exploitation. In this context, Chile has experienced several environmental movements, many of which have reached consolidation and national magnitude. Some of these transversal movements have been able to significantly impact the future of certain extraction projects as well as influence environmental policy-making (Silva, 2018).

Despite the limits that the development model has presented so far, Chile has shown no intention of changing the nondiversification pattern of the export economy, and its main mining company has disclosed its capability to continue its operations for at least seventy more years (Diario Financiero, 2015). Furthermore, Chile has strongly supported the Belt and Road Initiative, an intrinsically commercial megaproject, that would intensify the already massive Chilean exports to China.

\section{The Belt and Road Initiative in Chile}

According to Huang (2018), the Belt and Road Initiative is the realisation of Mao Zedong's desire, expressed in 1956, for China to become an industrialised country with the mandate and capability to make great contributions to humankind. Indeed, the Belt and Road Initiative might be understood as an expression of Chinese diplomatic culture rooted in Mao Zedong's philosophy. In 1946, Mao Zedong elaborated its Third World Theory, in which developing countries, 
located in the intermediate zone between the first and the third world, would unite forces against hegemonic powers. Mao's philosophy has greatly impacted Chinese policy until today, since after his thought, China has developed a diplomacy discourse based on cooperation between developing countries and win-win deals (Correa Vieira, 2019). In this sense, according to Muller-Markus (2016), the cornerstone of the current Chinese leader, Xi Jinping, is the so-called Chinese Dream -Renaissance of the Chinese nation-, which is explained in the desire to see China as a reemerge power, overcoming the past struggles under hegemonic forces. In this context, the Belt and Road Initiative, an infrastructure project which involves mainly developing countries, is an essential instrument to achieve the Chinese Dream. Undoubtedly, under the leadership of President $\mathrm{Xi}$, the aim for cooperation amongst developing countries has added to its political component an economic one. In this sense, the Belt and Road Initiative has been an example of the aiding and the cooperation China wants to pursue with developing countries, even if this represents high-risk investments in unstable countries (Correa Vieira, 2019).

The Belt and Road Initiative was introduced as a project aimed to build infrastructure and improve trade in certain regions of the globe (Ministry of Foreign Affairs of the People's Republic of China [MFA], 2013), but it has been unravelled into the biggest global project undertaken in contemporary times (González Sáez, 2019). The original idea of the BRI was to create an economic route through Central Asia, improving key infrastructure, in order to facilitate trade between all the countries involved, especially between Asia and Europe (MFA, 2013; The Belt and Road Construction Leadership Group, 2019). Later, an ambitious maritime route project was announced -The 21st Century Maritime Silk Road- (National Development and Reform Commission \& State Oceanic Administration, 2017), turning the BRI into a global-scale project. In order to successfully implement the BRI, China has established an important investment budget. Specifically, research related to The World Bank has identified USD\$575 billion worth of investment associated with BRI (Bandiera y Tsiropoulos, 2019).

In 2016, the BRI was extended to LAC, through the development of several economic-funding projects, where Chinese companies are set to play an important role in the development of these projects (González Sáez, 2019, p. 1). Although the BRI projects are frequently summed up as initiatives that aim to boost investment in hard infrastructure, the BRI also contemplates the participation of Chinese companies in the construction of digital infrastructure (The Belt and Road Construction Leadership Group, 2019). Indeed, Chile has extended its regular cooperation scope with Asia, centred in trade, to subjects such as telecommunications, new technologies, and data science (Undersecretariat of Telecommunications of Chile [SUBTEL], 2019). As a matter of fact, in recent years, Chile has achieved further commercial complementation with China and has set in motion digital infrastructure projects with Chinese companies.

In the Chilean case, the designation of BRI projects as such may be difficult for two reasons: firstly, the flexibility that the Initiative has shown so far, continuously extending the number of topics of cooperation over the years; secondly, the lack of primary sources that allows tracking BRI investment out of the overall Chinese funding within the Chilean economy. Despite this, there are at least two Initiatives of cooperation amongst the governments and companies of both countries that should be understood as a representation of the projects that China intends to implement through the BRI. The initiatives are (1) the deepening of trade between China and Chile, especially regarding agriculture and natural resources exports from Chile, and (2) the development of digital infrastructure through, mainly, two megaprojects: the Southern Optical Fiber project (FOA for its Spanish initials) and the Asia - South America Digital Gateway. These initiatives aim to improve commercial complementation, through trade agreements and the construction of key infrastructure.

\section{Further commercial cooperation between Chile and China}

Although the BRI comprehends international cooperation in different subjects, one of the key aspects of the Initiative is to ensure unimpeded trade amongst member countries (MFA, 2013). In this respect, the Initiative has been addressed by Chilean officials as a platform to extend and improve the economic integration between Chile and China (Ministry of Foreign Affairs of Chile [MINREL], 2018; Piñera, 2019a). Arguably, this is the reason why the development of further economic complementation between both countries is frequently situated within the Initiative's framework by media and officials of both countries (Heine, 2017; Liu, 2019; China Media Group [CMG], 2020).

Further trade between China and Chile, in the context of the BRI, represents the preservation of the productivity standard Chile has accomplished so far, and thus will not represent any adjustment to the economic challenges Chile faces in order to sustain its productivity. Although the BRI supposes the introduction of digital infrastructure, additional commercial integration in the context of the BRI, in specific, has not been complemented with the introduction of fixed capital in the export industry, neither diversification nor sophistication plans regarding production, and thus represents 
the persistence of the peculiarities of the export industry of Chile. The continuity of this pattern comprehends several problems in order to accomplish high and steady economic growth since the lack of technological innovation decreases the possibilities to diversify the productive sectors (French-Davis \& Díaz, 2019) and does not promote economic efficiency (UN, 2018) which entails a non-promising future in both economic and environmental aspects.

Likewise, further economic complementation between both countries will most likely imply the continuity of the environmental exploitation pattern of Chile as well. In the context of the Belt and Road Initiative, neither past nor further economic complementation agreements have been complemented with plans of sustainable management of environmental exploitation. Therefore, it is most likely that Chile will continue to show the same performance regarding some aspects of its ecosystem vitality, such as losses of environmental services, a high proportion of fishing in overexploited fish stocks -as the last EPI has shown- (Wendling, et al., 2020), as well as the social conflict produced by the socio-environmental implications of the environmental depletion.

Similarly, it is highly unlikely that the strengthening of commercial cooperation between China and Chile presents any change to the social issues Chilean society currently endures. Chilean authorities have not introduced any plan to overcome the inequality problems experienced by Chile, neither in the context of the economic dividends that the BRI should represent nor in the overall economic system. Indeed, Chile has experienced an increase in inequality and poverty rates due to the pandemic crisis, yet the authorities' aid was based on individual saving and indebtedness to overcome the problems presented by the income reduction of workers (Vega Salas, Caro, Valenzuela Egaña \& Testa, 2020). The continuation of the social disparities in Chile is challenging since, in recent years, mobilisation and social conflict, as consequences of inequality, have proven to be a destabilising factor for both economic and political systems.

The encouragement of economic complementation with China in the context of the BRI maintains the characteristic of the integration of Chile to international commerce as, mainly, a raw material source. This particular dimension of the BRI is not presenting a change to the social, productivity and environmental issues the country currently faces in order to achieve more sustainable development. Nonetheless, the digital infrastructure dimension of the Initiative comprehends projects that may present a change for the Chilean model.

\section{Optic Fiber for a Sustainable Future}

\subsection{Chilean Digital Agenda}

In the 2019' Belt and Road forum and a bilateral meeting between the governments of China and Chile, the latter was active in promoting an agenda centred on technological cooperation amongst both governments and Chinese companies (Luna, 2019; Piñera, 2019b). This scope of cooperation is innovative since the previous complementation between both countries was focused mainly on commerce.

The aforementioned agenda aims to expand the overall connectivity of the country and to introduce technological innovation, which subsequently would strengthen the economy and improve the position of Chile on global commerce. In this context, Chile intends to boost the optical fiber networks of the country, through projects such as the Southern Optical Fiber project, the development of 5G along the country, and the establishment of the Asia - South America Digital Gateway project (SUBTEL, 2019). The Southern Optical Fiber is a megaproject that answers to a national goal of reducing the digital gap between urban and rural communities. In particular, the project aims to boost the telecommunication access of communities located in the Southernmost zone of Chile, through the installation of 4500 kilometres of submarine and terrestrial fiber cables along three regions; Los Lagos, Aysen, and Magallanes (InvestChile, 2017; SUBTEL, 2020). Huawei is currently participating in the conduction of the project, becoming the biggest project developed by a Chinese company in Chile (MINREL, 2018).

Likewise, the Asia - South America Digital Gateway project intends to become the first optical fiber network to connect, directly, Asia and the LAC region (Xinhua, 2019), and thus, supposes, the most ambitious technological infrastructure project led by Chile. Both the 5G development and the Asia - South American transoceanic cable project have been formally presented to China as an invitation to participate in their tender processes (SUBTEL, 2019; Luna, 2019).

The digital agenda is especially necessary since Chile presents important limitations regarding telecommunication access for its population. In fact, the access to broadband within Chile is below OECD standards (OECD, 2018), and the existing fiber cables provide connection only within the Americas (Huichalaf Roa, 2020). As in other LAC countries, the lack of both access to the internet and poor digital competencies within some layers of the population of Chile are associated with socioeconomic, educational, gender, age, and spatial location -urban or rural areas- variables (United 
Nations Economic Commission for Latin America and the Caribbean [ECLAC], n.d., quoted in Brossard Leiva, 2016). Although in the past years the access to the internet of the overall population of the country has shown a significant increase, there is still $44 \%$ of the Chilean households that have no access to broadband (SUBTEL, 2018). Moreover, Los Lagos and Aysen regions, which will be directly affected by the FOA project, are part of the group of regions where the households experience the lowest access to broadband in the country (SUBTEL, 2017).

\subsection{Optic Fiber Innovation}

Undoubtedly, the development of more optical fiber networks will represent new possibilities for the Chilean case and, together with adequate regulations and incentives, a step forward to sustainable development. According to ECLAC, the reduction of the connectivity gap amongst countries and within nations represents a crucial step towards sustainable development, especially for LAC countries. For instance, the boost in telecommunications impacts positively the standards of efficiency of small companies, whilst the introduction of the internet within households enhances social development (2020). Moreover, the increase in economic efficiency and the access to information provided by telecommunications may represent instruments for environmental conservation as well (UN, 2018; The World Bank, 2016). These benefits are even more significant in the context of the pandemic, where technological barriers were introduced for businesses, employment, and education. Thus, the enhancement of connectivity becomes a necessary step in order to overcome the economic crisis presented by the pandemic (ECLAC, 2020).

Both optical fiber projects represent the introduction of connectivity and digital variables to the Chilean economy and, particularly, to the manner certain productivity processes have been carried out so far. These new variables could potentially enhance the productivity of the country and improve the position of Chile regarding economic complementation. The Southern Optic Fiber project might present substantial progress to the companies located in the Southernmost zone of Chile, especially to small enterprises that suffer from digital marginalisation. According to ECLAC (2020), the deepening of telecommunication access in small and medium-size businesses reports positive implications in productivity, since it allows innovation in the business management, production processes, and the provision of services. In the specific case of an important productive sector of Chile such as agriculture, several companies will be able to improve the management of the productive land, to achieve better use of resources, and to react satisfactorily to adverse situations, such as climate events or plagues, amongst other possibilities (Brossard Leiva, 2016, p, 101). The introduction of these new standards is only possible after the introduction of the internet, and are essential in order to compete in both international and domestic markets (Brossard Leiva, 2016).

Likewise, the transoceanic cable project represents a change in the overall connectivity of Chile and in the way this country conducts commerce with its more important economic partners located in Asia. According to the OECD and the World Trade Organization (2017), the efforts in digital connectivity, and its consequences, are significant for a country's commerce since they directly affect the value chain, reducing the cost of the exchange of products, whilst enhancing efficiency in the organisation of the productive procedures, the transportation of goods and the logistic processes. In the particular case of Chile, it is expected that the operation of the transoceanic cable encourages the digitalisation of productive processes, leading to economic efficiency, and subsequently, contributing to the sustainable development for Chile and the rest of Latin America (Carranza, 2019 quoted in Development Bank of Latin America, 2019).

Regardless of the plenty of opportunities mentioned above, it is important to understand that connectivity is essential to achieve positive results, yet it is not sufficient (The World Bank, 2016, p.4). It may be a mistake to assume that the mere advances in telecommunications will improve economic standards. In this sense, economic expansion cannot be accomplished if the regulations of the country do not promote an economic environment for innovation. For instance, regulations such as the non-allowance of incumbent companies to control the market entry, or policies that encourage the full leverage of digital technologies in order to innovate and compete are critical in order to accomplish the results that telecommunications can provide for an economy (The World Bank, 2016).

But if the economic efficiency aforementioned is actually achieved, both projects could improve the environmental performance of Chile as well. The provision of access to the internet is the foundation stone for the introduction of new technologies to an economy. These new technologies are strongly related to the efficiency of the economies, decreasing the emissions and improving the management and use of resources, which has a positive impact on the protection of the environment. Many of these new technologies, such as electric transportation or renewable energies, have the potential to reduce emissions, yet an important proportion of the world ignores the long-run benefits these technologies provide, which is why access to information about these issues is essential (UN, 2018).

Connectivity may also provide more access to information by different communities, which helps to create a better understanding of environmental sustainability. Much of the environmental problems the world currently experiences 
require global management and cooperation, which are impossible to accomplish without telecommunications. In this respect, the internet is a key instrument to create awareness and global cooperation over the environmental challenges the world is now facing. Also, the internet amplifies the impact of different organisations, allowing more people to participate in the formulation and execution of plans towards sustainable development (The World Bank, 2016).

The possibility to access new and more information provided by connectivity infrastructure has also social implications, especially when allowing the development of human capital. The projects that this paper discusses represent changes in the social development possibilities of several communities, especially if new technologies and digital competencies are introduced to these communities. According to ECLAC (2020), the provision of telecommunication access to the portions of the population that have been marginalised from digital advances has the potential to widens the access to education and employment, especially during Covid times, and, also, provides the possibility for political institutions to become more inclusive and participative organisations. The population marginalised from digitalisation has been the most affected by the technological requirements that the pandemic has introduced to daily living and, therefore, the provision of telecommunications represents a key policy in order to overcome the pandemic crisis.

Nevertheless, as in the case of productivity, complementary regulations are necessary as well in order to accomplish positive social and environmental outcomes from connectivity. The increase of access to the internet without the provision of digital skills for the population will not achieve the opening of social opportunities, such as education, employment, and political participation (ECLAC, 2020). Likewise, political institutions will not become more inclusive and participatory organisations just by the mere existence of internet access, but with the active creation of digital participation policies, as well as the presence of digital skilled public servants that may innovate in those policies (The World Bank, 2016).

Although the digital infrastructure goals of Chile, in the context of the BRI, are guided towards further economic complementation amongst Chile and the globe, this agenda, undoubtedly, represents innovative features for Chilean development. Nevertheless, the positive impact that the digital agenda may or may not have over social, economic and environmental dimensions do not depend on the boost of connectivity exclusively. Despite the fact that the provision of the internet is crucial and represents, in many cases, a foundation stone for the introduction of new standards and technologies, there are other correlative variables that also determine the impact connectivity has on sustainable development.

\section{Conclusions}

The purpose of this investigation was to examine the changes and continuities that both telecommunications and commercial dimensions of cooperation between Chile and China represent to the model of development of Chile, in the context of the Belt and Road Initiative. The article, firstly, outlines briefly the main sustainability issues the Chilean development has presented so far and, subsequently, tries to discuss the innovation or preservation that the aforementioned dimensions of cooperation may present to those issues. It is argued that, indeed, the dimensions of cooperation between Chile and China introduce elements of both continuities and changes to the characteristics of Chilean development.

The first dimension of cooperation between Chile and China is the preservation of the current commercial cooperation between them, and the achievement of further complementation between both countries. This dimension contemplates the enhancement of Chinese participation within Chilean export, which represents the continuity of China as the top destination of agriculture and natural resources goods of Chile. Thus, this represents a continuity of the commercial pattern of Chilean development which entails several challenges.

The open economy principle Chile has followed in the past years has created wealth and has improved Chile's population quality of life. This growth has, nevertheless, been achieved in spite of significant problems: severe inequality, simplistic productivity, and environmental depletion. It is noted that, within and outside of the BRI context, the absence of governmental plans aimed towards the redistribution of the dividends of growth, the sophistication of productivity, and the sustainable management of natural resources, has led Chile to face the sustainability challenges presented so far.

Nonetheless, the cooperation over connectivity between Chile and China may present changes for the model of development adopted by Chile as well. Chile is currently pursuing a digital agenda, aimed at the provision of telecommunication networks to the overall population, through the FOA and the Asia - South America transoceanic cable projects. This agenda will increase the connectivity of Chile to the rest of the world and, thereby, aspires to improve the position of Chile within international commerce, but this time through telecommunications innovation. In 
addition, the agenda will also increase access to the internet within the country, reporting a change to the population, especially those communities that have been marginalised from digitalisation.

International organisations advocate for the positive outcomes that connectivity frequently adds to the sustainable development of the nations since it opens new opportunities for human capital development, increases productivity and economic efficiency, and aids the current fight against the climate adversities the world currently faces. In this sense, the outcomes of the digital agenda pursued by Chile could be promising, but these international organisations also outline the regulations and incentives that the use of the internet should be complemented with. Ultimately, the provision of digital skills for the population and the creation of a proper economic environment to innovate and compete are essential to achieve the outcomes expected from connectivity, especially if the goal is to take steps towards sustainable development. Therefore, the policies and encouragement established by Chile in addition to the boost of connectivity will be significant in how the changes introduced by telecommunications will shape the characteristics of Chilean development.

\section{Acknowledgements}

The author is grateful for the helpful discussions with Luis Clavería, Professor Xu Luo and Professor Jiang Xueqin.

\section{Bibliography}

Bandiera, L., \& Tsiropoulos, V. (2019). “Framework to Assess Debt Sustainability and Fiscal Risks under the Belt and Road Initiative. Policy Research Working Paper”. (8891), 1-56 World Bank. https://doi.org/10.1596/1813-9450-8891

Brossard Leiva, F. (2016). "Hacia un modelo de inclusión digital rural. Una mirada sobre América Latina y el caso de Chile”. Nueva Sociedad. 262 (March-April 2016), 97-107. Access Date: May 4th, 2021 https://dialnet.unirioja.es/ servlet/articulo? codigo $=5434041$

Carrasco, S., \& Maillet, A., (2019). “30 años de institucionalidad ambiental en Chile: entre la esperanza y las promesas incumplidas (1990-2018)”. Camila Carrasco (Ed.), Chile y Cambio Climático. Ciudad de México: FriedrichEbert-Stiftung.

Castiglioni, R. (2019). “¿El ocaso del <<modelo chileno>>?”. Nuso, Nov-Dec (284), 4 - 14. Access date: April 27th, 2021 https://www.nuso.org/articulo/el-ocaso-del-modelo-chileno/

China Media Group (1st of January, 2020). La Franja y la Ruta: el megaproyecto de infraestructura que impulsa China del que Chile es parte. La Tercera. Access date: May 4th, 2021 https://www.latercera.com/conexion-china/noticia/lafranja-la-ruta-mega-proyecto-infraestructura-impulsa-china-del-chile-forma-parte/956856/

Correa Vieira, V. (2019). "From Third World Theory to Belt and Road Initiative: International Aid as a Chinese Foreign Policy Tool”. Contexto Internacional. 41(3). 529-252. Access date: June 4th, 2021 http://dx.doi.org/10.1590/S0102$\underline{8529.2019410300003}$

Development Bank of Latin America (12th of July, 2019). Chile and CAF to lead feasibility study for the first digital gateway between South America and Asia. Development Bank of Latin America News. Access date: March 29th, 2021 https://www.caf.com/en/currently/news/2019/07/chile-and-caf-to-lead-feasibility-study-for-first-digital-gatewaybetween-south-america-and-asia/

Diario Financiero (14th of May, 2015). Codelco: tenemos reservas para sustentar nuestras operaciones por los próximos 70 años. Diario Financiero. Access date: May 3rd, 2021 https://www.df.cl/noticias/empresas/mineria/codelco-tenemosreservas-para-sustentar-nuestras-operaciones-por-los-proximos-70-anos/2015-05-14/161050.html

French-Davis, R, \& Díaz, A. (2019). "La inversión productiva en el desarrollo económico de Chile: evolución y desafíos". Revista de la CEPAL, 2019 (127), 27 - 53. Access date: April 27th, 2021 https://doi.org/10.18356/fba7fde1-es 
González Sáez, R. (2019). “The Chinese Project “One Belt One Road” Toward Latin America and the Caribbean. Economicfinancial implication”. Journal of Evolutionary Studies in Business. 4(2) 108-131, https://doi.org/10.1344/jesb2019.2.j062

Heine, J. (15th of May, 2017). Chile en Cumbre sobre la Franja y la Ruta en Beijing. La Tercera. Access date: May 20 th, 2021 https://www.latercera.com/voces/chile-cumbre-la-franja-la-ruta-beijing/

Huang, H. (2018). "De la adhesión a la "OMC” a la "Franja y la Ruta”. 40 años 40 conjuntos de palabras clave". Observation Scope View. 2019(1). Access date June 4th, 2021. https://mp.weixin.qq.com/s/3zcb5rz4rBrUdBnB13k6Og

Huichalaf Roa, P. (24th of February, 2020). La Ruta de la Seda Digital. La Tercera. Access date: April 10th, 2021 https:// www.latercera.com/conexion-china/noticia/la-ruta-la-seda-digital/1019455/

Huneeus, C. (2018). "La democracia semisoberana y la representación política tecnocrática”. Huneeus, C \& Avendaño, O, (Eds.), El sistema político de Chile. Santiago: LOM.

InvestChile. (27th of June, 2017). 10 key questions about the Southern Optical Fiber Project. Date access: April 12 th, 2021. https://investchile.gob.cl/10-key-questions-about-the-southern-optical-fiber-project/

Klaus, S, \& World Economic Forum (Eds). (2019). Global Competitiveness Report 2019. World Economic Forum. Access date: April 27th, 2021. http://www3.weforum.org/docs/WEF TheGlobalCompetitivenessReport2019.pdf

Liu, R. (6th of May, 2019). La Franja y la Ruta: qué significa para Chile. Diario Financiero. Access date: May 4th, 2021 https:// www.df.cl/noticias/opinion/columnistas/la-franja-y-la-ruta-que-significa-para-chile/2019-05-06/153949.html

Londoño, E. (12th of August, 2017). Chile's Energy Transformation is Powered by Wind, Sun, and Volcanoes. New York Times. Access date: May 26th, 2021 https://www.nytimes.com/2017/08/12/world/americas/chile-green-energygeothermal.html

Luna, P. (5th of May, 2019). Tras gira por Asia, Piñera busca convertir a Chile en plataforma de inversiones para la región. France 24. Access date: March 29th, 2021 https://www.france24.com/es/20190505-chile-china-pinera-xi-huawei

Martner, G. (2017). Matriz productiva, transformación Social-ecológica y el rol de los actores económicos. Análisis / Friedrich Ebert Stiftung Chile, 2017(3), 1 - 20. Access date: 27th April, 2021 http://library.fes.de/pdf-files/bueros/ chile/14161.pdf

Ministry of Foreign Affairs of Chile (2018). Canciller Ampuero firma acuerdo de Cooperación entre Chile y China de la iniciativa de la Franja y la Ruta. Access date: March 25th, 2021 https://www.prochile.gob.cl/noticia/canciller-ampuerofirma-acuerdo-de-cooperacion-entre-chile-y-china-de-la-iniciativa-de-la-franja-y-la-ruta/

Ministry of Foreign Affairs of the People's Republic of China (2013). Promote Friendship Between Our People and Work Together to Build a Bright Future. Speech by H.E. Xi Jinping. https://www.fmprc.gov.cn/mfa eng/wjdt 665385/ zyjh 665391/t1078088.shtml

Muller-Markus, C. (2016). “One Belt, One Road: the Chinese Dream and its impact in Europe”. Notes International CIBOD. 148(May 2016), 1-6. Access date, June 4th, 2021 https://www.cidob.org/ca/publicacions/series de publicacio/notes internacionals/n1_148_one_belt_one_road_el_sueno_chino_y_su_impacto_sobre_europa/one_belt_one_road_the_ chinese_dream_and_its_impact_on_europe

National Development and Reform Commission (2017). Vision for Maritime Cooperation under the Belt and Road Initiative. State Council. March 27th, 2021 https://eng.yidaiyilu.gov.cn/zchj/qwfb/16639.htm

National Development and Reform Commission \& State Oceanic Administration (2017). Vision for Maritime Cooperation under the Belt and Road Initiative. https://eng.yidaiyilu.gov.cn/zchj/qwfb/16639.htm

Norman, S. (29th of July, 2020). Goodbye to Plastic Bags in Chile. Plastic Oceans. March 22nd, 2021 https://plasticoceans.org/ goodbye-to-plastic-bags-in-chile/\#: :text=In\%202018\%20Chile $\% 20$ implemented $\% 20$ the,the $\% 20$ Environment $\% 20$ Minister\%2C\%20Carolina\%20Schmidt.

Ominami, C. (2010). “Chile: una transición paradojal. Notas para un examen crítico”. Quiroga, Y. \& Ensignia, J. (Eds.), 
Chile en la Concertación [1990-2010] Tomo II. 21-61. Santiago: Friedrich Ebert Stiftung. Access date: April 16th, 2021 https://library.fes.de/pdf-files/bueros/chile/07499.pdf

Organisation for Economic Cooperation and Development (28th of June, 2018). Actualización de estadisticas de banda ancha de la OCDE. Access date: April 10th, 2021 https:/www.oecd.org/centrodemexico/medios/ actualizaciondeestadisticasdebandaanchadelaocde.htm

Organisation of Economic Cooperation and development \& World Trade Organisation (2017). La ayuda para el comercio en sintesis 2017: Fomentar el comercio, la inclusión y la conectividad en favor del desarrollo sostenible. May 4th, 2021 https://www.wto.org/spanish/res_s/booksp_s/aid4trade17_poket_s.pdf

Piñera, S. [@sebastianpinera]. (28th of April, 2019b). Intensa y fructífera visita a China. Acuerdos con Pdte Xi Jinping en 14 áreas muy import para Chile. Nos reunimos con empresas + innovadoras en electromovilidad, intelig artificial, energías limpias y tecn $5 \mathrm{G}$ q nos permitirán ser parte de soc conoc e inform y mejorar calidad vida. [Tweet]. https://twitter.com/ sebastianpinera/status/1122514144673062913

Piñera, S. [@sebastianpinera]. (27th of April, 2019a). Foro Una Franja Una Ruta impulsado x China q hoy participamos abre nuevas oportunidades de colaboración, conectividad, libre comercio e integración entre países, respetando legislación e identidad de c/u y promoviendo mayor desarrollo, oportunidades y bienestar para los chilenos. [Tweet]. https://twitter. com/sebastianpinera/status/1122183987294875653

Silva, E. (2018). "Mega-Projects, Contentious Politics and Institutional and Policy Change”. European Review of Latin American and Caribbean Studies, 106 (July-December, 2018), pp. 133-156. https://doi.org/10.32992/erlacs.10391

The Belt and Road Construction Leadership Group (2019). The Belt and Road Initiative Progress, Constructions and Prospects. State Council. Access date: May 14th, 2021 https://eng.yidaiyilu.gov.cn/zchj/qwfb/86739.htm

The World Bank (2016). Development world report. Digital dividends. Access date: May 4th, 2021 https://www.worldbank. org/en/publication/wdr2016

Undersecretariat of Foreign Economic Affairs (2019). Impacto de los Tratados de Libre Comercio. Hacia una politica inclusiva. Ministry of Foreign Affairs of Chile. https://www.subrei.gob.cl/estudios-y-documentos/presentaciones/ detalle-presentaciones/impacto-de-los-tratados-de-libre-comercio

Undersecretariat of Telecommunications of Chile (17th of May, 2018). 44\% de los hogares del país no tiene conexión fija a Internet. Ministry of Transports and Telecommunications of Chile. Access date: April 14th, 2021 https://www.subtel.gob. cl/44-de-los-hogares-del-pais-no-tiene-conexion-fija-a-internet/

Undersecretariat of Telecommunications of Chile (23rd of October, 2020). Habitantes de Puerto Williams podrán acceder a conectividad móvil de alta velocidad gracias a la Fibra Óptica Austral. Ministry of Transport and Telecommunications of Chile.March 25th, 2021 https://foa.subtel.gob.cl/habitantes-de-puerto-williams-podran-acceder-a-conectividadmovil-de-alta-velocidad-gracias-a-la-fibra-optica-austral/

Undersecretariat of Telecommunications of Chile (25th of April, 2019). Subsecretaria Pamela Gidi en gira por Asia: como Gobierno queremos estar preparados para el desarrollo de redes de alta velocidad y Asia es un referente tecnológico para concretarlo. Ministry of Transport and Telecommunications of Chile. Access date: March 17th, 2021. https:// www.subtel.gob.cl/subsecretaria-pamela-gidi-en-gira-por-asia-como-gobierno-queremos-estar-preparados-para-el$\underline{\text { desarrollo-de-redes-de-alta-velocidad-y-asia-es-un-referente-tecnologico-para-concretarlo/ }}$

Undersecretariat of Telecommunications of Chile (December 2017). IX Encuesta de Acceso y Usos de Internet. Informe Final. Ministry of Transport and Telecommunications of Chile. Access date: March 26th, 2021 https://www.subtel.gob. cl/estudios/internet-y-sociedad-de-la-informacion/

United Nations Economic Commission for Latin America and the Caribbean (2019). Panorama social para América Latina. United Nations. https://www.cepal.org/es/publicaciones/44395-panorama-social-america-latina-2018

United Nations Economic Commission for Latin America and the Caribbean (2020). Perspectivas económicas de América Latina 2020. Transformación Digital Para una Mejor Reconstrucción. (LC/PUB.2020/10). United Nations https://www. cepal.org/es/publicaciones/46029-perspectivas-economicas-america-latina-2020-transformacion-digital-mejor 
United Nations (1987). Report of the World Commission on Environment and Development: Our Common Future (A/42/427). United Nations https://sustainabledevelopment.un.org/content/documents/5987our-common-future.pdf

United Nations (2018). Estudio económico y social mundial 2018: Tecnologías de vanguardia en favor del desarrollo sostenible. Sinopsis. (E/2018/50). https://www.un.org/development/desa/dpad/wp-content/uploads/sites/45/ WESS2018-overview sp.pdf

UnitedNations(n.d.).FrequentlyAskedQuestions.DateAccess:March8th,2021 https://www.un.org/sustainabledevelopment/ development-agenda/

Vega Salas, M.J., Caro, P., Valenzuela Egaña, R. \& Testa. N. (31st of August, 2020). Análisis comparativo de la política social económica chilena durante la pandemia. Ciper. Access date March 11th 2021 https://www.ciperchile.cl/2020/08/31/ analisis-comparativo-de-la-politica-social-economica-chilena-durante-la-pandemia/

Vergara, J. (2005). “El mito de las privatización en Chile”. Polis Revista Latinoamericana. 12 (2005), 1-9. http://journals. openedition.org/polis/5604

Wendling, Z. A., Emerson, J. W., de Sherbinin, A., \& Esty, D. C., et al. (2020). "2020 Environmental Performance Index". Yale Center for Environmental Law \& Policy. Access date: April 5th, 2021 https://epi.yale.edu/

World Ocean Initiative (24th of June, 2020). Chile's Marine Protected Areas: a case study in coastal governance?. Access date: April 12th, 2021 https://ocean.economist.com/governance/articles/chile-marine-protected-areas-a-case-studyin-coastal-governance

Xinhua (9th of May, 2019). Chile adjudica estudio de factibilidad de cable submarino Sudamérica-Asia. Xinhua. http:// spanish.xinhuanet.com/2019-09/05/c 138365722.htm 